\title{
Indicators for monitoring and assessment of Environmental management systems in ports
}

\author{
Farah Housni ${ }^{1, *}$, Amal Maurady ${ }^{1}$, Philip Barnes ${ }^{2}$, Abderrazak Boumane ${ }^{1}$, and Mohamed Reda Britel $^{1}$ \\ ${ }^{1}$ Innovative technology laboratory,University of Abdelmalek Essaadi,Tangier,Morocco \\ ${ }^{2}$ Environment and Sustainability Program University of South Carolina, Columbia, South Carolina, United States
}

\begin{abstract}
Ports are no longer content with being the connection of ocean and land transportation, of which they are keys in international logistics and supply chains. Ports have also become industrial production areas. As ports continue to evolve as production areas, they are becoming significant sources of water pollution, solid waste, and noise and air pollution. Due to this increase in environmental impacts, the majority of the world ports have made commitments to development of proactive procedures for a sustainable development by adopting an environmentally responsible approach to preserve and protect the environment. This is despite the need of a diagnostic tool which allows monitoring and evaluation of the progress of environmental management in the different sectors of the port. The present study evaluated the different activities and environmental aspects related to the shipping industry and identified the main indicators to assess and develop an environmental management system (EMS) in order to achieve sustainable development.
\end{abstract}

\section{Introduction}

Ports have evolved from the central point where cargoes and passengers are loaded and discharged, to the multimodal distribution hubs that link sea, road, rail, and air routes [1-2]. Nowadays, the innovation of systems and new technology created competition and forces changes in the international logistics chain, including ports, to conduct business in the future [3].

In this context storage demand, deeper waterways, larger terminal space for ship handling and warehousing, inlands roads and rail access has resulted in ports becoming industrial production areas similar to large industrial operations, therefore increasing the ports environmental aspects and negative environmental impacts. [4].

This new dynamic of the port system has led to studies from different approaches. In this regard, Bichou and Gray analyzed the port system from three overviews [5]:

-Macro-analytical: including the ports relationships with public policies, actions that drive the growth of the port and its environmental perspective.

- Micro-analytics: analyzing internal issues as well as relationships with cargo and passenger transfers and their integration into the logistics chains.

- Hybrid: combining elements from the previous sections as well as the role and functions of the port.

Elsewhere, Paixao and Marlow classified ports into four generations, taking into account the terrestrial/maritime transport interface, the provision of services and consolidation of loads, those linked to the production and logistics chains and, finally, the use of just-in-time and lean production techniques in terms of management[6]. In building on Paixo and Marlow's port classification, research conducted in the middle and late 2000 's emphasizes the fifth and sixth generation ports [78-9].

However industrial ports continue to produce negative substantial externalities on the local and regional level with considerable environmental impacts such as noise disturbance, air pollution and visual impediments [10]. Also, some of the impacts such as sea level rise, high winds, and storm surges can have considerable impacts on ports' facilities, which could endanger a region's import and/or export [11-12-13].

As mentioned, the shipping industry is the vital component of the maritime transport chain and cargohandling productivity consequently plays an important role in determining the competitiveness of maritime transport, against other transport modes [14]. The majority of the world ports is aware of their environmental impact and has made commitments to the development of proactive procedures for a sustainable development by adopting an environmentally responsible approach to preserve and protect the environment. The sustainable development commitments also allow at the same time, the port to achieve the objective of port development combined with sustainable environmental management in a win-win strategy.

In the literature review for this paper a set of environmental performance indicators was proposed to assess the environmental performance related to ports. The reviewed studies evaluate the performance of

\footnotetext{
Farah Housni: farah.housni20@gmail.com
} 
operational (dust, noise, dredging, and waste) or managerial (certification, compliance, and complaints) as well as conditions (air, water, sediment and ecosystems) of the port [15-16-17-18]. This paper emphases the importance to monitor and assess the port using an EMS structure that highlights the above indicators through an analysis of the EMS Environmental policy, tracking environmental performance, reviewing environmental performance alternatives and integrating sustainable development goals applicable to the port. The indicator based on the port's identified significant impacts selected using the structure of ISO 14001 EMS will guide port managers toward a sustainable development. As port indicators are monitored and measured, the port can better control the management, environmental performance, and overall port conditions.

In this paper we will first quote and analyze the different environmental aspects related to identified shipping industry activities, integrating the problems caused by the port activity itself, due to ships calling at the port such as emissions from inter-modal transport networks serving the port. We will then propose indicators to monitor and assess the port's environmental management system. Through monitoring the indicators identified in this research the port will identify gaps in their EMS. The analysis and the reduction of the port environmental aspects will lead to continual improvement of environmental management tools, which allows monitoring and evaluating the progress of environmental management in the different sectors of any global maritime port setting.

As discussed in the introduction to this study, ports have expanded their operations into additional production capabilities. As ports have expanded their operational processes, the environmental aspects and impacts have also expanded as indicated through our literature review and assessment of port operations. The study conclusion discusses how four areas of an EMS, emphasized in this paper, provide port managers with the opportunity to complete a self-assessment, identify environmental and sustainability indicators, monitor and measure port growth and progress in order to develop the EMS and sustainable development plans in ports.

\section{Port impact}

There were 8,096 global maritime ports in 2018 that were considered the most fuel efficient mode of transport and important in global trade [19]. Currently, it is predicted that World seaborne trade will grow by a factor of $2.5 \%$ from 2020 to 2040[20].

Knowing that each port has three areas contributing to environmental impacts [21]:

-Impacts related to the port activity itself;

-Impacts related to ships calling at the port;

-Emissions from inter-modal transport networks serving the port.

These impacts vary depending upon the port infrastructure, location, networks and actions taken by port managers on the issues addressing environmental impacts (commitment to reduce air pollution, water pollution, solid waste pollution and energy reduction....).

In order to analyze and determine the impact it is important to detect and record all the aspects of the port activities and select those that could have significant impact. Figure 1 presents the activities identified in the different types of port (passengers, cargo, industrial...) [22]. Figure 2 presents the environmental aspects to the port activity [23]. Knowledge of the environmental aspects is required in order to have effective port environmental management awareness [24].

Of course port activities are based on a port's trade and service to customers; therefore they come in all types and sizes. The activities and their environmental aspects in the tables provided are based on the continued growth of ports and will be useful for all port managers reading this study. Though ports continue to expand operations to serve customer needs, including the cities where the port is located tables 1 and 2 demonstrate the change in activities and their environmental aspects over a period of time that indicate growth in production areas, as shown. Ports continue to change processes through continual improvement, however, as this paper demonstrates, as ports use an EMS new activities can easily be brought into the EMS structure and assessed in order to manage them as part of the ports environmental management program.

\begin{tabular}{|c|c|c|}
\hline $\begin{array}{l}\text { Port priority actirities: } \\
\text {-Administrative services } \\
\text {-Bunkering } \\
\text {-Dredging } \\
\text {-Disposal of dredged m aterial } \\
\text { - Marine-ba sed cargo transport } \\
\text { (Shipping) } \\
\text {-Land-ba sed cargo transport (train, } \\
\text { truck, car, etc.) } \\
\text {-Passengers transportation (ferry \& } \\
\text { cruise shipss) } \\
\text {-Fishing \& Aqua culture activities } \\
\text {-Maintenance of port installations and } \\
\text { infra structure } \\
\text {-Maintenance of port vehicle and } \\
\text { equipm ent } \\
\text {-Ship building, repair and } \\
\text { m aintenance } \\
\text {-Port developm ent } \\
\text {-Pilotage } \\
\text {-Towing } \\
\text {-Mooring } \\
\text {-Marina sand yacht clubs } \\
\text {-Water sports } \\
\text {-Port Waste Mana gem ent }\end{array}$ & $\frac{\text { The main ports }}{\text { actirities }}$ & $\begin{array}{l}\text { Port based industry: } \\
\text {-Aggregate industry } \\
\text {-Chemical \& pham aceutical plants } \\
\text {-Fish m arket and processing } \\
\text {-Ago foodIndustries } \\
\text {-Metal ore processing and refining } \\
\text {-Oil refineries } \\
\text {-Power stations } \\
\text {-Steel works }\end{array}$ \\
\hline
\end{tabular}

Figure 1. List of the main ports activities

\begin{tabular}{|c|c|c|}
\hline $\begin{array}{l}\text { Biodir ersity } \\
\text { affectation: } \\
\text {-Ecosystem s and habitats }\end{array}$ & $\begin{array}{l}\text { Noise: } \\
\text { Noise em issions }\end{array}$ & $\begin{array}{l}\text { Emissions to soil: } \\
\text {-Emissions to soil and } \\
\text { groundwater }\end{array}$ \\
\hline & Enrironmental a spect & \\
\hline $\begin{array}{l}\text { Discharges to } \\
\text { water/sedim ents: }\end{array}$ & of port actirity & $\begin{array}{l}\text { Resource consumption: } \\
\text {-Water consum ption }\end{array}$ \\
\hline -Discharges of & $\downarrow$ & -Fuel consumption \\
\hline wastewaters & Emissions to air: & -Waste production \\
\hline -Discharges of & -Emissions of & -Generation of solid \\
\hline $\begin{array}{l}\text {-Discharges of other } \\
\text { chemicals }\end{array}$ & -Emissions of other & -Generation of hazardous \\
\hline $\begin{array}{l}\text {-Discharges of } \\
\text { particulate matter }\end{array}$ & -Emissions of particulate & $\begin{array}{l}- \text { Generation of other } \\
\text { wastes }\end{array}$ \\
\hline
\end{tabular}

Figure 2. Environmental aspect of port activity 
Management of the port aspects can increase or decrease their impact on the environment. The identification and assessment of environmental aspects is one of the requirements and essential tasks for the development and implementation of an Environmental Management System (EMS). Aspects have to be monitored and evaluated. The lack of a diagnostic tool makes this evaluation process one of the most complicated tasks in the environmental management system of a port.

\section{Assessment and evaluation of EMS in ports}

There are various types of EMS that demonstrate a systematic approach to environmental management, such as a regulatory management system or other models including the European Eco-Management and Auditing Scheme (EMAS) or the ISO 14001 EMS. These standards present a broad range of approaches, tools, frameworks, principles, strategies and processes which can confuse if not understood in relation to a framework for sustainability.

The international maritime organization (IMO) is also trying to guide the ports by convention through applications such as International Convention for the Safety of Life at Sea (SOLAS), International Convention for the Prevention of Pollution from Ships (MARPOL)...[25]. Port managers need a clear framework suitable for all the environmental aspects of port authorities, not only those related to the ships, in order to effectively grapple with the challenge of moving toward a sustainable port.

Therefore, in developing strategies to meet specific United Nations sustainable development environmental goals the port's best strategic approach is to use the ISO 14001:2015 EMS [26]. In this context there are four significant areas of the ISO 14001 that will guide port managers toward a sustainable development. Whatever the environmental management system approved by the port, in order to attain sustainable development, port managers must take into consideration these four headings, which are described below in regard to the importance to sustainable development practices:

\subsection{Environmental policy}

The environmental policy is an essential pillar of the EMS and ensures its direction and intent as well as effectiveness. The environmental policy guides the management of the environmental aspects and assures the application of the national and international environmental regulations in coordination with port leadership supporting the EMS through providing resources and provides the opportunity to build upon the principles of sustainability.

Through working with stakeholders to impose its environmental initiatives, planning studies with fixed targets to meet, and benchmarking with other ports to revise the port EMS policy provides the intent and guidance for efficient management of the impacts of significant aspects building the foundation of sustainable development.

\subsection{Improvement of environmental performance}

To develop the EMS port management must continually improve environmental performance through describing environmental impacts of the ports. This is completed by scheduling manager reviews of the port's environmental performance to assist in support of the environmental policy that proposes methods to monitor and measure environmental performance.

All parties, especially ship captains, must be in communication when discussing the port's environmental performance goals. This provides the ability to propose trainings about contribution to the reduction of environmental impact and continually reviewing the sustainable development goals.

This progress is recorded and the port's environmental performance should be distributed to all stakeholders in order for them to understand their responsibility in meeting the port's sustainable development goals.

\subsection{Environmental performance alternatives}

In order to increase its environmental performance the port must try to reduce the substances as defined by MARPOL Annex 1-6, encourage the use of clean technologies and option to alternate energy (fuel type) as well as the reuse and recycle of resources used in shipping, such as ballast water treatment and residue/waste/spill control.

Good programming, logistic and scheduling efficiency such as reduction of idle and waiting times is required to reduce air emissions and increase the use of environmentally friendly shipping equipment and facilities. The port should also present incentives to green ships by proposing reduction of price for the ships using LNG.

In reviewing environmental performance alternatives port managers can align their environmental management practices to encompass sustainable development goals.

\subsection{Sustainable development goals applicable by port}

Among the 17 United Nations sustainable development goals, seven of them could be applied by interested ports: Goal 7: Affordable and clean energy; Goal 9: Industry, Innovation and Infrastructure; Goal 11: Sustainable cities and communities; Goal12: Responsible consumption and production; Goal 14: Life below water; Goal 15: Life on land; Goal17: Partnerships for the goals [27].

For each one of these headings there are several indicators. Table 1 details the indicators that are important to track. The port must absolutely not neglect these indicators, especially since sustainable development has become pertinent to the maritime and port industries for supporting and facilitating continued growth in trade by providing cargo-handling facilities, transshipment and other auxiliary services for ships 
without compromising the environmental, social, or economic aspects [28].

Table 1. Indicators for sustainable development port

\begin{tabular}{|c|c|c|c|}
\hline $\begin{array}{l}\text { Environment } \\
\text {-al policy }\end{array}$ & $\begin{array}{c}\text { Improvement } \\
\text { of } \\
\text { environment } \\
\text { al } \\
\text { performance }\end{array}$ & $\begin{array}{c}\text { Environmenta } \\
\text { I performance } \\
\text { alternatives }\end{array}$ & $\begin{array}{c}\text { Sustaina- } \\
\text { ble } \\
\text { develop- } \\
\text { ment } \\
\text { goals } \\
\text { applicab- } \\
\text { le by } \\
\text { port }\end{array}$ \\
\hline $\begin{array}{l}\text { Application of } \\
\text { national and } \\
\text { international } \\
\text { environmental } \\
\text { regulations }\end{array}$ & $\begin{array}{c}\text { Guidelines } \\
\text { describing } \\
\text { environmental } \\
\text { impacts }\end{array}$ & $\begin{array}{c}\text { Reduction of } \\
\text { substances as } \\
\text { defined by } \\
\text { MARPOL } \\
\text { Annex 1-6 }\end{array}$ & $\begin{array}{c}\text { Goal7: } \\
\text { Affordab- } \\
\text { le and } \\
\text { clean } \\
\text { energy }\end{array}$ \\
\hline $\begin{array}{l}\text { Leadership } \\
\text { support in } \\
\text { providing } \\
\text { resources }\end{array}$ & $\begin{array}{l}\text { Scheduled } \\
\text { manager } \\
\text { review of the } \\
\text { environment- } \\
\text { tal } \\
\text { performance }\end{array}$ & $\begin{array}{l}\text { Use of clean } \\
\text { technologies } \\
\text { and option to } \\
\text { alternate } \\
\text { energy (fuel } \\
\text { type) }\end{array}$ & $\begin{array}{c}\text { Goal9: } \\
\text { Industry, } \\
\text { Innovati- } \\
\text { on and } \\
\text { Infrastruc } \\
\text {-ture }\end{array}$ \\
\hline $\begin{array}{l}\text { Working with } \\
\text { stakeholders } \\
\text { to impose } \\
\text { environment- } \\
\text { al initiatives }\end{array}$ & $\begin{array}{l}\text { Methods to } \\
\text { monitor and } \\
\text { measure } \\
\text { environment- } \\
\text { tal } \\
\text { performance }\end{array}$ & $\begin{array}{l}\text { Reuse and } \\
\text { recycle of } \\
\text { resources used } \\
\text { in shipping }\end{array}$ & $\begin{array}{c}\text { Goal11: } \\
\text { Sustainab } \\
\text {-le cities } \\
\text { and } \\
\text { communi } \\
\text {-ties }\end{array}$ \\
\hline $\begin{array}{l}\text { The reduction } \\
\text { of resources } \\
\text { to meet } \\
\text { sustainability } \\
\text { goals }\end{array}$ & $\begin{array}{l}\text { Ship captains } \\
\text { are included in } \\
\text { communicatio } \\
\mathrm{n} \text { of the port's } \\
\text { environment- } \\
\text { tal } \\
\text { performance } \\
\text { goals. }\end{array}$ & $\begin{array}{l}\text { Ballast water } \\
\text { treatment and } \\
\text { residue/waste/ } \\
\text { spill control }\end{array}$ & $\begin{array}{l}\text { Goal12: } \\
\text { Responsi- } \\
\text { le } \\
\text { consumpt } \\
\text {-ion and } \\
\text { producti- } \\
\text { on }\end{array}$ \\
\hline $\begin{array}{c}\text { Meeting } \\
\text { percentages of } \\
\text { the targets } \\
\text { fixed on the } \\
\text { basis of } \\
\text { studies }\end{array}$ & $\begin{array}{l}\text { Review of } \\
\text { sustainable } \\
\text { development } \\
\text { goals are } \\
\text { scheduled and } \\
\text { progress is } \\
\text { recorded. }\end{array}$ & $\begin{array}{l}\text { Logistic and } \\
\text { scheduling } \\
\text { efficiency for } \\
\text { such as } \\
\text { reduction of } \\
\text { idle and } \\
\text { waiting times }\end{array}$ & $\begin{array}{l}\text { Goal 14: } \\
\text { Life } \\
\text { below } \\
\text { water }\end{array}$ \\
\hline $\begin{array}{l}\text { Percentage of } \\
\text { benchmarking } \\
\text { completed } \\
\text { with other } \\
\text { ports to revise } \\
\text { your EMS }\end{array}$ & $\begin{array}{c}\text { The port's } \\
\text { environment- } \\
\text { tal } \\
\text { performance } \\
\text { plan is } \\
\text { distributed to } \\
\text { all } \\
\text { stakeholders. }\end{array}$ & $\begin{array}{c}\text { Use of } \\
\text { environmentall } \\
\text { y friendly } \\
\text { shipping } \\
\text { equipment and } \\
\text { facilities }\end{array}$ & $\begin{array}{c}\text { Goal 15: } \\
\text { Life on } \\
\text { land }\end{array}$ \\
\hline $\begin{array}{l}\text { Management } \\
\text { of the impact } \\
\text { of the } \\
\text { significant } \\
\text { aspect }\end{array}$ & $\begin{array}{c}\text { Port } \\
\text { stakeholders } \\
\text { know and } \\
\text { understand } \\
\text { their } \\
\text { responsibility } \\
\text { in meeting the } \\
\text { port's } \\
\text { sustainable } \\
\text { development } \\
\text { goals }\end{array}$ & $\begin{array}{l}\text { Reduction of } \\
\text { price for the } \\
\text { ships using } \\
\text { LNG }\end{array}$ & $\begin{array}{l}\text { Goal17: } \\
\text { Partner- } \\
\text { ships for } \\
\text { the goals }\end{array}$ \\
\hline
\end{tabular}

\section{Conclusion}

Since environmental sustainability became a pressing issue for maritime shipping management, ports must demonstrate an interest and ability in analyzing and reducing the environmental aspects of port activity in order to reduce the ports environmental impacts.

As mentioned above, container traffic increases, ports continually increasing in size and throughput to compete in the global trade increases the port's environmental pollution. The EMS and sustainable development plans in ports serve a role to make this growth transpire without imposing additional externalities that harm the environment.

Port authorities must find ways to continually improvement their EMS. The four areas discussed are significant points of an EMS that port managers must manage and control in order to better build the port's EMS to support the UN's sustainable development goals. This study presents discussion and guidelines to assist global ports in better understanding the importance of completing a self-assessment, identifying environmental and sustainability indicators, monitoring and measuring progress in order to attain sustainable development.

The four areas emphasized in this paper provide port managers with the opportunity to implement best practices to reduce their environmental impacts at both the local and global levels. These points are classified under four headings Environmental Policy; Criteria for improving port performance; Environmental performance alternatives, and Performance devoted to Sustainable Development.

This study is ongoing by the authors who are researching and presenting diagnostic tools, that will allow the evaluation of continuing progression of environmental and sustainability management, which will strengthen the continual improvement process of the EMS.

\section{References}

1. Y.C. Yang, S.L. Chen, Determinants of global logistics hub ports: comparison of the port development policies of Taiwan, Korea, and Japan. Transport Pol 45, 179-189, (2016)

2. Y. Song, N. Wang, Exploring temporal and spatial evolution of global coal supply-demand and flow structure. J. Energy 168, 1073-1080 (2018)

3. Port Reform tool kit, second module: The Evolution of Ports in a Competitive World. Retrieved from https://ppiaf.org/sites/ppiaf.org/files /documents/toolkits/Portoolkit/Toolkit/module2/por t_dynamics.html

4. J.P. Rodrigue, Theo. Notteboom, Port Terminals, Ports and Sites, chapter 4, The Geography of Transportation Systems, Fourth Edition, New York, Routledge, ISBN 978-1138669574 (2017).

5. K. Bichou, Chapter 24, Review of port performance approaches and a supply chain 
framework to port performance benchmarking. Res. Transport. Econ. 17, 567-598 (2016)

6. A.C. Paixao, P.B. Marlow, P.B. Fourth generation ports - a question of agility? Int. J. Phys. Distrib. Logist. Manag 33, 355-376 (2003)

7. J.S.L Lam, D..W. Song, Seaport network performance measurement in the context of global freight supply chains. POL MARIT RES 20, 47-54 (2013)

8. P.T Lee, P. T. W., J. S. L. Lam, Container port competition and competitiveness analysis: Asian major ports. Handbook of ocean container transport logistics, Switzerland: Springer, Cham (2015)

9. A. Kaliszewski, Fifth and sixth generation ports $(5 G P, 6 G P)$ - evolution of economic and social roles of ports. Factors contribution to competitiveness (2018)

10. M.T. Acciaro, C.Vanelslander,C.Ferrari, A. Roumboutsos, G. Giuliano, J. S. L. Lam, and K. Kapros. Environmental Sustainability in Seaports: A Framework for Successful Innovation. Marit Pol Manag 41, 480-500. doi:10.1080/03088839.2014.932926 (2014)

11. S. Hanson, RJ. Nicholls .Extreme flood events and port cities through the twenty-first century. Maritime transport and the climate change challenge. Earthscan/Rutledge, New York, p. 24 (2012)

12. A.H. Becker, A note on climate change adaptation for seaports: a challenge for global ports, a challenge for global society. Clim. Change 120, pp.683-695. Available at:http://link.springer.com/10.1007/s10584-0130843-Z. (2013)

13. Ng, A. K. Y., Wang, T., Yang, Z., Li, K. X., Jiang, C. How is Business Adapting to Climate Change Impacts Appropriately? Insight from the Commercial Port Sector. J. Bus. Ethics..Available at: http://link.springer.com/10.1007/s10551-0163179-6 (2016)

14. K. Cullinane, M. Khanna .Economies of scale in large containerships: optimal size and geographical implications. J. Transp. Geogr. 8, 3, 181-195 https://doi.org/10.1016/S09666923(00)00010-7 (2000)

15. C. Saengsupavanich, N. Coowanitwong, W.G. Gallardo, C. Lertsuchatavanich. Environmental performance evaluation of an industrial port and estate: ISO14001, port state control-derived indicators, J.Prod pp. 154-161 (2009)
16. M. Puig, C. Wooldridge, R.M. Darbra Identification and selection of Environmental Performance Indicators for sustainable port development Mar. Pollut. Bull, 81 ,pp. 124-130 (2014)

17. M. Puig, C. Wooldridge, A. Michail, R.M. Darbra.Current status and trends of the environmental performance in European ports. Environ Sci Policy, 48 , 57-66 (2015)

18. R. Teerawattana, Y.C. Yang, Environmental Performance Indicators for Green Port Policy Evaluation: Case Study of Laem Chabang Port, Asian J. Shipp. Logist, 35, 1, 63-69 (2019)

19. American Association of Port Authorities. Alliance of the Ports of Canada, the Caribbean, Latin America and the United States, Port Industry Statistics (2018)

20. J.U. Schröder-Hinrichs ,E. Hollnagel,M. Baldauf,S Hofmann ,A. Kataria, Marit Pol Manag ,40 ( 2013)

21. Environmental Impacts of International Shipping, the Role of Ports, Organization for Economic Cooperative Development (OECD)(2011)

22. EcoPorts Foundation. Guidelines for Self Diagnosis Method SDM. Version 1.4 (2004).

23. M. Puig, C. Wooldridge, J. Casal, R.M. Darbra ,Tool for the identification and assessment of Environmental Aspects in Ports (TEAP).Ocean \& Coastal Manag. 113 , 8-17 (2015)

24. ESPO (European Sea Ports Organization), Port Environmental Review System (PERS). A Portsector Specific Methodology to Start Implementing an Environmental Management System. Version 4. ESPO, Brussels (2011)

25. IMO,International maritime organization. Maritime human factors and IMO policy .Retrieved from http://www.imo.org/en/About/Conventions/Pages/ Home.aspx (2020)

26. ISO (International Organisation for Standardisation). ISO 14001:2015 Environmental Management Systems

27. United nations sustainable development goals.Retrieved from https://www.sightsavers.org/policy-andadvocacy/globalgoals/?gclid=Cj0KCQjw9b_4BRCMARIsADMUI ypR7YCVhFfnBvZxwQx6atbLzCp0fFON_b8CzIj 0cWkOGI68aft2I8aAtNGEALw_wcB (2015)

28. D. Kiron,N. Kruschwitz, , K. Haanaes, M. Reeves, E. Goh . The innovation bottom line. MIT Sloan Manag. Rev. 54,3(2013) 